\title{
High prevalence of hepatitis $C$ associated with familial history of hepatitis in a small town of south Brazil. Efficiency of the rapid test for epidemiological survey
}

\begin{abstract}
This report describes a cross-sectional survey on the prevalence of hepatitis C antibodies (anti-HCV) in Tamboara, a small community in the northwest area from Paraná State, south of Brazil with a high rate of accumulated detection for HCV. Eight hundred and sixteen residents (17.87\% from all the population), independently of the age and time living in Tamboara were included in this study by an epidemiologic questionnaire and by testing for anti-HCV. The rapid immuno-chromatographic test was applied for detection of HCV antibodies. The anti-HCV prevalence by rapid test was $4.28 \%$. The median age for positive and negative test was $60.49 \pm 14.14$ and $41.67 \pm 20.25$, respectively $(\mathrm{p}<0.001)$. By multivariate analysis, only familial history of hepatitis $(\mathrm{p}=0.001$; $\mathrm{OR}=6.41$; CI $95 \%=2.08-19.78)$ and age $(\mathrm{p}=0.007$; OR $1.06 ; 95 \% \mathrm{CI}=1.02-1.10)$ showed statistical significance for positive anti-HCV. The rapid test sensitivity and specificity were $100 \%$ and $92.7 \%$ respectively, with an accuracy of $95.8 \%(95 \%$ CI $=91-100)$. These findings demonstrated a high prevalence of anti-HCV in Tamboara. The familial history of hepatitis was a significant risk factor to the infection and HCV rapid test showed to be accurate and feasible for epidemiological survey.
\end{abstract}

Keywords: hepatitis C, epidemiology, Brazil.

[Braz J Infect Dis 2010;14(5):483-488] @Elsevier Editora Ltda.

\section{INTRODUCTION}

Hepatitis $\mathrm{C}$ virus (HCV) infection represents a major public health problem in Brazil and in the world. Most of the cases are asymptomatic HCV carriers, but chronic infection occurs in approximately $85 \%$ of the infected individuals that can progress into liver cirrhosis and hepatocarcinoma. The HCV was identified in 1989 by researchers from Chiron Corporation and it is responsible for about $90 \%$ of the so-called non-A non-B hepatitis. ${ }^{1}$ Presently, cirrhosis caused by chronic hepatitis $\mathrm{C}$ is the leading indication for liver transplantation in United States of America ${ }^{2,3}$ and in Brazil. ${ }^{4}$

After tests to detect anti-HCV became available, a number of studies have been conducted to estimate the prevalence of $\mathrm{HCV}$ infection in the general population..$^{5-9}$ The World Health Organization (WHO) data suggests a worldwide prevalence of $2.2 \%$ -
$3.0 \%$, with the highest prevalence found in the African and the Eastern Mediterranean regions. ${ }^{10}$ Brazilian studies on this subject have been predominantly targeted risk groups ${ }^{11-14}$ and blood donors. ${ }^{15,16}$ Only few investigators have addressed the prevalence of hepatitis $\mathrm{C}$ in the general population or in minority groups. ${ }^{17}$ Focaccia et al., for example, found $1.42 \%$ of anti-HCV positive results in the population of São Paulo. ${ }^{18}$ In Brazilian blood donors, the anti-HCV prevalence was found to be $1.6 \%{ }^{13}$ In the South Region the prevalence in general population and blood donors was estimated in $0.15 \%{ }^{14,19}$ and $0.46 \%,{ }^{20}$ respectively.

Considering data from public health department, the Paraná State from 2003 to 2006 has an accumulated detection of 21.11 cases of hepatitis C per 100,000 inhabitants. But in Tamboara, this rate was estimated on 581.95. ${ }^{21}$ Based on this fact, we conducted a
Authors

Cláudia Alexandra Pontes

Ivantes, $\mathrm{MD}^{1}$

Danilo Silva, MD

Iara Messias-Reason, $\mathrm{MD}, \mathrm{PhD}^{1}$

${ }^{1}$ Department of Internal Medicine, Universidade Federal do Paraná, Curitiba, PR, Brazil.

Submitted on: 3/8/2010 Approved on: 5/21/2010

Correspondence to: Cláudia Ivantes Rua: Euclides da Cunha 1259 apto 601 Bigorrilho Curitiba - PR - Brazil CEP: 80730-360 E-mail: civantes@uol. com.br

The authors accepted and received Rapid Test Bioeasy ${ }^{\circledR}$ as donation from Roche. 
study to investigate the prevalence of anti-HCV in Tamboara residents and to elucidate the risk factors associated with HCV transmission in this population. The results should help sanitary authorities to set up policy decisions for Tamboara. For this community-based seroepidemiological survey, HCV Rapid Test was used and validated by ARCHITECT quimioluminescent immunoassay.

\section{MATERIALS AND METHODS}

\section{Study population}

This study was performed in Tamboara, a small town with 4,564 inhabitants of the Paraná State, south Brazil. The town was divided in different areas which were visited by groups of two investigators. Each house of urban area has been systematically visited by a trained nursing student. One resident for each house, independently of age, was selected by at random and invited to participate in the study. Blood sample and a questionnaire on the risk factors for hepatitis $\mathrm{C}$ were obtained from each subject after the informed consent was signed. In the case of minors, the informed consent was signed by their parents. The questionnaire consist of questions regarding demographic variables, familial history of hepatitis, various potential parenteral exposure to blood or blood products before and after 1993, history of parenteral injections and intravenous drips, sexual behavior, as well as dental treatment, previous surgery, tattooing, etc. The study protocol was approved conformed to the ethical guidelines of the 1975 Declaration of Helsinki, as reflected in a priori approval by the institution's Human Research Committee.

\section{Laboratory testing}

The HCV Rapid Test Bioeasy (Bioeasy Diagnostica Ltda, Minas Gerais, Brazil), an immuno-chromatographic assay for HCV antibodies qualitative detection was used according to the manufacturer's instructions. Briefly, total blood from each subject was obtained by lancing device against the chosen puncture finger and $10 \mu \mathrm{L}$ was aspirated with a micropipette. The blood was deposited in a small slide and 3 drops of the reagent were added. After ten minutes, one column if negative or two columns if positive could be viewed. When the anti-HCV was positive by Rapid Test Bioeasy, the result was confirmed by ARCHITECT quimioluminescent immunoassay (Abbott Park, IL, USA), considered the gold standard for antiHCV detection. Ten percent of negative patients were invited to confirm their test as well. Those subjects, whose results were positive in both tests, were further tested by PCR (Amplicor ${ }^{\circledR}$ Hepatitis C Virus - HCV - Test, version 2.0, Roche, Branchburg, NJ, USA) for HCV RNA detection and genotyping by kit VERSANTTM VERSANT
HCV Genotype Assay (LiPA) (Bayer, Tarrytown, NY, USA), according to the manufacturer's instructions. In a second step, the families' members from HCV positive patients were contacted and invited to have their antiHCV status checked by Rapid Test Bioeasy. The positive results were than confirmed by PCR (Amplicor ${ }^{\circledR}$ Hepatitis C Virus - HCV - Test, version 2.0, Roche, Branchburg, NJ, USA) for HCV RNA detection.

\section{Statistical analysis}

Risk factors were compared between patients with positive or negative HCV testing using $\chi^{2}$ test or Fischer's test as appropriated. For calculation of anti-HCV prevalence related to age, Student's t-test was applied. Multivariate analysis was conducted using logistic regression, considering Wald test for variable significance. Rapid test was validated by sensibility and specificity determination. A $\mathrm{p}$ value $<0.05$ was considered statistically significant.

\section{RESULTS}

\section{Seroprevalence by age and gender}

During a period of 4 days, 816 (17.87\%) subjects of 4,564 estimated residents in Tamboara were interviewed and tested for anti-HCV. The overall anti-HCV prevalence using Rapid Test Bioeasy was 4.28\% (35 subjects), similar in males $(3.85 \%)$ and females $(4.53 \%)$. The anti$\mathrm{HCV}$ prevalence according to age is showed in Figure 1. The median age for positive and negative anti-HCV test was $60.49( \pm 14.14)$ and $41.68( \pm 20.25)$ years old respectively, with a $\mathrm{p}$ value $<0.001$.

Figure 1: Distribution of anti-HCV prevalence by age groups in the population of Tamboara, Brazil.

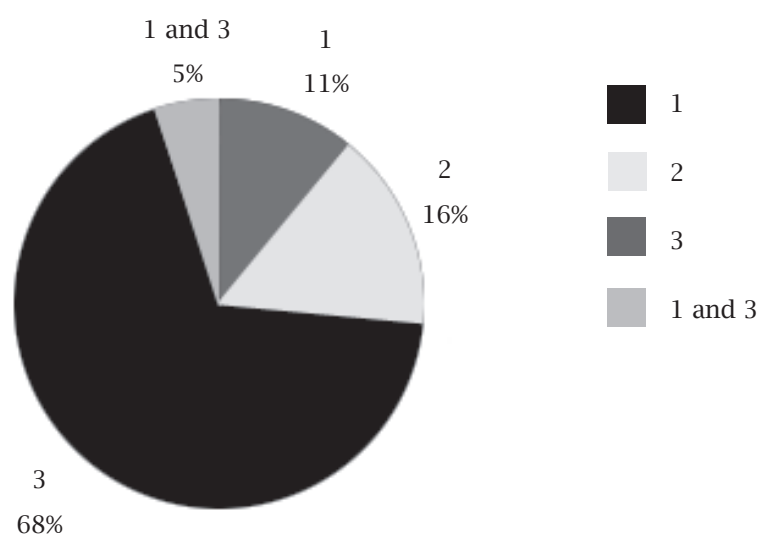




\section{Socioeconomic factors}

The social-demographic variables are demonstrated in Table 1. Ethnic group and marital status were not associated with presence of HCV infection. The prevalence of anti-HCV in subjects with no education or less than eight years of education was significantly higher than in the others ( $\mathrm{p}=0.012$ ). Sadly, $15.14 \%$ of the population in Tamboara had less than one year of education.

\section{Risk factors for hepatitis C}

By univariate analysis, the significant risk factors for HCV infection were as follow: familial history of hepatitis $(\mathrm{p}=0.04)$, injection with glass syringe $(\mathrm{p}<0.001)$, vaccination with jet (needle-free) injection devices $(\mathrm{p}=0.034)$, blood transfusion before 1993 $(\mathrm{p}<0.001)$ and not safe sexual practice $(\mathrm{p}=0.03)$. By multivariate analysis, only familial history of hepatitis $(\mathrm{p}=0.001 ; \mathrm{OR}=6.41 ; 95 \% \mathrm{CI}=2.08-19.78)$ and age $(\mathrm{p}=0.007$; OR $1.06 ; 95 \% \mathrm{CI}=1.02-1.10)$ showed statistically significant values (Table 2 ). Based on that, we constructed a ROC curve in order to identify an age associated to positive HCV status. After that, only participants with more than 45 years $(n=362)$ of age were analyzed. By multivariate analysis of this group, familial history of hepatitis continued to be the only significant risk factor of HCV infection ( $\mathrm{p}=0.001$; OR 5.08; $95 \%$ CI $=1.99-12.99)$ (Table 3$)$.

\section{Rapid Test Bioeasy performance}

The sensibility and specificity of the Rapid Test Bioeasy was estimated considering quimioluminescent immunoassay as gold standard for anti-HCV. Thirty three anti-HCV positive individuals and 41 anti-HCV negative by immuno-chromatographic test were submitted to quimioluminescent immunoassay (Table 4 ). The sensitivity and specificity was $100.0 \%$ and $92.7 \%$ respectively, with an accuracy of $95.8 \%$ $(95 \% \mathrm{CI}=91-100)$.

Table 1. Sociodemographic characteristics and anti-HCV positivity in the population of Tamboara, Brazil

\begin{tabular}{|c|c|c|c|c|}
\hline \multirow[t]{2}{*}{ Category } & \multirow[t]{2}{*}{ n (\%) } & \multicolumn{3}{|c|}{$\begin{array}{c}\text { Anti-HCV } \\
\text { Rapid Test Bioeasy }\end{array}$} \\
\hline & & Negative (\%) & Positive (\%) & $p$ value \\
\hline \multicolumn{5}{|l|}{ Gender } \\
\hline Female & $530(64.95)$ & $506(95.47)$ & $24(4.53)$ & 0.646 \\
\hline Male & $286(35.05)$ & 275 (96.15) & $11(3.85)$ & \\
\hline \multicolumn{5}{|l|}{ Ethinic group } \\
\hline Euroupeans & 469 & 447 (95.31) & $22(4.69)$ & 0.802 \\
\hline Africans & 111 & 107 (96.4) & $4(3.6)$ & \\
\hline Asians & 20 & 25 (89.29) & $3(10.71)$ & \\
\hline Mixed race & 200 & $194(97)$ & $6(3)$ & \\
\hline Native indians & 8 & $8(100)$ & $0(0)$ & \\
\hline \multicolumn{5}{|l|}{ Education } \\
\hline $0-7$ years & 437 & 409 (93.59) & $28(6.41)$ & 0.012 \\
\hline$\geq 8$ years & 316 & 309 (97.78) & $7(2.22)$ & \\
\hline \multicolumn{5}{|l|}{$\begin{array}{l}\text { Marital status } \\
\qquad(\geq 14 \text { years })\end{array}$} \\
\hline $\begin{array}{l}\text { Never married, } \\
\text { divorced or } \\
\text { widower }\end{array}$ & 286 & 275 (96.15) & $11(3.85)$ & 0.526 \\
\hline Married & 469 & 445 (94.88) & $24(5.12)$ & \\
\hline
\end{tabular}


Table 2. Risk factors associated with HCV among participants

\begin{tabular}{|lcc|}
\hline Variable & p value & $\begin{array}{c}\text { Odds ratio } \\
\text { (95\% CI) }\end{array}$ \\
\hline Years of education & 0.208 & $2.49(0.60-10.34)$ \\
\hline $\begin{array}{l}\text { Familial history } \\
\text { of hepatitis }\end{array}$ & 0.001 & $6.41(2.08-19.78)$ \\
\hline Surgery & 0.829 & $0.88(0.27-2.90)$ \\
\hline $\begin{array}{l}\text { Injection with } \\
\text { glass syringe }\end{array}$ & 0.612 & $1.54(0.29-8.14)$ \\
\hline $\begin{array}{l}\text { Jet injection device } \\
\text { Sutures }\end{array}$ & 0.319 & $3.12(0.33-29.51)$ \\
\hline $\begin{array}{l}\text { Blood transfusion } \\
\text { before 1993 }\end{array}$ & 0.758 & $0.85(0.29-2.47)$ \\
\hline $\begin{array}{l}\text { Blood transfusion } \\
\text { after 1993 }\end{array}$ & 0.306 & $2.22(0.48-10.29)$ \\
\hline $\begin{array}{l}\text { Not safe sexual } \\
\text { practice }\end{array}$ & 0.490 & $2.14(0.24-18.75)$ \\
\hline \begin{tabular}{l} 
Age \\
\hline
\end{tabular} & 0.007 & $1.06(1.02-1.10)$ \\
\hline
\end{tabular}

Table 3. Risk factors associated with $\mathrm{HCV}$ in participants older than 45 years of age

\begin{tabular}{lcc|}
\hline Variable & p value & $\begin{array}{c}\text { Odds ratio } \\
(\mathbf{9 5 \%} \text { CI) }\end{array}$ \\
\hline $\begin{array}{l}\text { Familial history } \\
\text { of hepatitis }\end{array}$ & 0.001 & $5.08(1.99-12.99)$ \\
\hline $\begin{array}{l}\text { Injection with } \\
\text { glass syringe }\end{array}$ & 0.310 & $2.92(0.37-23.26)$ \\
\hline $\begin{array}{l}\text { Blood transfusion } \\
\text { before 1993 }\end{array}$ & 0.178 & $2.25(0.69-7.35)$ \\
\hline $\begin{array}{l}\text { Blood transfusion } \\
\text { after 1993 }\end{array}$ & 0.082 & $3.82(0.84-17.40)$ \\
\hline
\end{tabular}

Table 4. Performance of the Rapid Test Bioeasy in the detection of anti-HCV

\begin{tabular}{l|c|c|c}
\hline \multirow{2}{*}{ Rapid Test Bioeasy } & \multicolumn{2}{|c|}{$\begin{array}{r}\text { Quimioluminescent } \\
\text { immunoassay }\end{array}$} & \multirow{2}{*}{ Total } \\
\cline { 2 - 3 } & positive & negative & \\
\hline positive & 30 & 3 & 33 \\
\hline negative & 0 & 38 & 38 \\
\hline total & 30 & 41 & 71 \\
\hline
\end{tabular}

\section{Genotype distribution}

The prevalence of HCV genotypes is shown in Figure 2. Sixty-eight percent of positive anti-HCV residents were genotype 3 and only $11 \%$ were genotype 1 .

Figure 2: Prevalence of hepatitis $C$ virus genotypes in the population of Tamboara, Brazil.

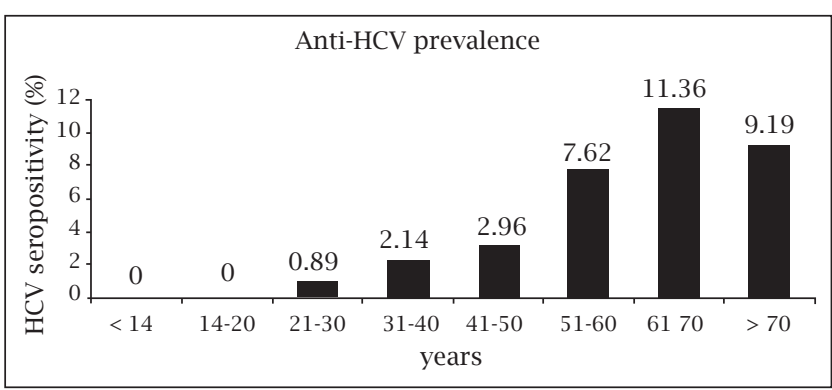

\section{HCV status from family members of positive residents}

Seventy eight family members from 28 anti-HCV positive subjects were investigated for anti-HCV with 5 (6.41\%) of them showing positive results by Rapid Test Bioeasy and by PCR. The five anti-HCV positive were from 3 different families.

\section{DISCUSSION}

There are only few population-based studies on age-specific prevalence of HCV infection which demonstrate distinct epidemiologic profiles of $\mathrm{HCV}$ transmission worldwide. These profiles reflect not only regional variations but also variations in the period during which there was an increased risk for acquiring HCV infection. In Tamboara, the age-specific antiHCV prevalence is low in children and younger adults but increases sharply among older persons, who account for most of the infected individuals. The data suggests that the burden of disease might have already peaked. This type of pattern was also seen in Spain, ${ }^{22}$ Italy $^{6}$ and Japan ${ }^{23}$ and it is consistent with the fact that the risk for $\mathrm{HCV}$ infection was highest $30-50$ years ago. Illegal use of injection drugs have been the dominant mode of HCV transmission in USA during the past 30 years ${ }^{7}$ but it appears to have played a minor role in the population of Tamboara. In countries where the period of increased risk for HCV infection occurred in a distant past such as observed in this study, healthcare-related procedures performed both by professionals and nonprofessionals appear to have been a major mode of HCV transmission. The authorities responsible for health care in Tamboara had a hypothesis that the high prevalence of anti-HCV was related with jet injection devices. Up to 1990, vaccination with this technique was used especially for prevention of yellow fever in Brazil. An epide- 
miological survey by Souto et al. in a Center-West Brazilian city suggests that the jet injection device has facilitated hepatitis B contamination in the population..$^{24}$ In this study, some healthcare procedures related to anti-HCV transmission were identified by univariate analysis. Injections with glass syringe, vaccination with jet injection devices and blood transfusion before 1993 were significant risk factors. However, by multivariate analysis, these factors were not significant.

In a recent survey, prevalence for anti-HCV ranging from 0.69\%- $1.89 \%$ was observed in the capital cities of Northeast, Center-West and in Federal District of Brazil. ${ }^{25}$ In Tamboara, this prevalence was $4.3 \%$ is considered high for a place with not known risk factors. The strong relationship of risk of infection and the presence of family history of hepatitis suggests that the transmission of HCV have occurred among family members, but does not define the exact routes. As hypothesized by Rao et al., many infections in the past were probably acquired from external sources in which more than one family member was contaminated at the same time. ${ }^{26}$ Nevertheless, the lower prevalence in younger age groups in Tamboara suggests that the unknown exposure may no longer play a role in HCV transmission.

According to Campiotto et al., the HCV genotype 1 is more prevalent in all regions of Brazil with a median frequency of $64.9 \%$ and in the South, genotype 3 was more common $(43.2 \%)$ than in the other regions. ${ }^{27}$ Similar results were found by Focaccia et al. ${ }^{28}$ In hemodialysis patients from Central Brazil, the genotype 3 was present in $7.6 \%{ }^{29}$ In Tamboara, the great majority of $\mathrm{HCV}$ individuals carry genotype 3 .

The study found a $6.41 \%$ prevalence of anti-HCV in members of the positive families. This data confirms the important role of intrafamilial transmission in our population.

The accumulated incidence and anti-HCV prevalence in Tamboara has called the attention of local health care workers. Thus, better knowledge regarding this HCV epidemic area was important for the government to take effective decisions strategies. Based on this data, we now know that infection occurred in a distant past and there is no longer risk behavior related to HCV. Efforts from government and local health workers will become necessary for treating already infected subjects. This effort will be extremely efficient in avoiding cirrhosis and hepatocellular carcinoma and it will have a social economic result better than the HCV prevention in Tamboara. The great majority of individuals infected by genotype 3 will become this strategy result even better and less expensive since genotype 3 virus has good response to interferon and ribavirin treatment.

By our knowledge, this epidemiological survey was the first in Brazil to check the quality of the Rapid Test Bioeasy for anti-HCV as a screening test. The sensibility of a rapid immuno-chromatographic assay for the detection of anti$\mathrm{HCV}$ antibodies have been evaluated previously on 421 HCV RNA positive samples from chronic carriers and com- pared with enzyme-linked immunoassays (ELISA) method. ${ }^{30}$ The sensitivity of rapid test was $95.5 \%$ and false negative results were associated with human immunodeficiency virus (HIV). Among HIV-negative people, the sensibility was $99.2 \%$ whereas among HIV positive one, this result was $77.5 \%$. In our study, a specificity of $92.7 \%$ and accuracy of 95.8\% was observed for rapid test. Since Tamboara presents low HIV prevalence rates with only one positive case in 2007, the HIV status had not influenced rapid test performance. In this case, the test has showed to be simple, accurate and feasible, with adequate sensibility and specificity. Based on this data, the immuno-chromatographic test for anti-HCV showed to be appropriated for population-based studies, in settings with limited facilities or when rapid results are required.

In conclusion, our data show high prevalence of antiHCV positivity associated with familial history of hepatitis in a small town of south Brazil. The immuno-chromatographic rapid test has shown to be efficient in population based surveys.

\section{ACKNOWLEDGEMENTS}

The authors wish to thank the nursing staff of the State Faculty of Education, Science and Literature from Paranavaí and the Paraná State Health Department for their encouragement and support. The authors also are grateful to all participants and Roche for the donation of Rapid Test Bioeasy ${ }^{\circledR}$.

\section{REFERENCES}

1. Choo QL, Kuo G, Weiner AJ et al. Isolation of a DNA clone derived from a blood-borne non-A, non-B viral hepatitis genome. Science 1989; 244:359-362.

2. Shiffman ML, Saab S, Fengs $S$ et al. Liver and intestine transplantation in the United States, 1995-2004. American Journal of Transplantation 2006; 6:1170-1187.

3. Gringeri E, Vitale A, Brolese A et al. Hepatitis C virus-related cirrhosis as a significant mortality factor in intention-to-treat analysis in liver transplantation. Transplantation Proceedings 2007; 39:1901-1903.

4. Associação Brasileira de Transplante de Órgãos (ABTO) Database. (http://www.abto.org.br/abtov02/portugues/populacao/ rbt/rbt10anos/index.aspx?idCategoria=2). Accessed 13 August 2009.

5. Abdel-Aziz F, Habib M, Mohamed MK et al. Hepatitis C virus (HCV) infection in a community in the Nile delta: population description and HCV prevalence. Hepatology 2000; 32:111-115.

6. Stefano RD, Stroffolini T, Ferraro D et al. Endemic hepatitis $\mathrm{C}$ virus infection in a Sicilian town: further evidence for iatrogenic transmission. Journal of Medical Virology 2002; 67:339-344.

7. Alter MJ, Kruszon-Moran D, Nainan OV et al. The prevalence of hepatitis C virus infection in the United States, 1988 through 1994. New England Journal of Medicine 1999; 341:556-562. 
8. Domínguez A, Bruguera M, Vidal J et al. Community-based seroepidemiological survey of HCV infection in Catalonia, Spain. Journal of Medical Virology 2001; 65:688-693.

9. Sun CA, Chen H, Lu S et al. Persistent hyperendemicity of hepatitis $\mathrm{C}$ virus infection in Taiwan: the important role of iatrogenic risk factors. Journal of Medical Virology 2001; 65:30-34.

10. Lavanchy D. The global burden of hepatitis C. Liver International 2009; 29 (Suppl 1):74-81.

11. Ivantes $\mathrm{CA}$, Amarante $\mathrm{H}$, Ioshii SO, Pasquini R. Hepatitis $\mathrm{C}$ virus in long-term bone marrow transplant survivors. Bone Marrow Transplantation 2004; 33:1181-1185.

12. Carvalho M, Branco PP, Luvizotto ML et al. High prevalence of hepatitis $\mathrm{C}$ virus infection in chronic hemodialysis patients. Brazilian Journal of Infectious Diseases 1999; 3:144-148.

13. Carrilho FJ, Silva LC. Epidemiologia. In: Silva LC, ed. Hepatites Agudas e Crônicas. São Paulo: Sarvier, 1995: pp. 73-95.

14. Braga ACM, Reason IJM, Maluf ECP et al. Leprosy and confinement due to leprosy show high association with hepatitis C in southern Brazil. Acta Tropica 2006; 97:88-93.

15. Patiño-Sarcinelli F, Hyman J, Camacho LA et al. Prevalence and risk factors for hepatitis $\mathrm{C}$ antibodies in volunteer blood donors in Brazil. Transfusion 1994; 34:138-141.

16. Gonçales Jr FL, Pedro RJ, Silva LJ et al. Hepatites pós-transfusionais na cidade de Campinas, SP, Brasil. 1l. Presença de anticorpos anti-HBc e anti-HCV em candidatos a doadores de sangue e ocorrência de hepatites pós-transfusionais pelo vírus $\mathrm{C}$ nos receptores de sangue ou derivados. Revista do Instituto de Medicina Tropical de São Paulo 1993; 35:63-71.

17. Ferreira A, Greca D, Tavares E et al. Seroepidemiology of hepatitis B and C infection in Kaingang Indians from south Brazil. Revista Panamericana de Salud Pública 2006; 20:230-235.

18. Focaccia R, Conceição OJ, Sette H Jr et al. Estimated prevalence of viral hepatitis in the general population of the municipality of São Paulo, measured by a serologic survey of stratified, randomized and residence-based population. Brazilian Journal of Infectious Diseases 1998; 2:269-284.
19. Fonseca JC. Epidemiologia da infecção pelo vírus da hepatite C no Brasil. Relatório de estudo da Sociedade Brasileira de Hepatologia. GED 1999; 18:S3-S8.

20. Ministério da Saúde Database. (http://portal.saude.gov.br/ portal/saude/Gestor/visualizar_texto.cfm?idtxt=27220). Access 14 August 2009.

21. SINAN. (http://tabnet.datasus.gov.br/cgi/deftohtm). Access 20 August 2009.

22. Dominguez A, Bruguera M, Vidal J et al. Community-based seroepidemiological survey of HCV infection in Catalonia, Spain. Journal of Medical Virology 2001; 65:688-693.

23. Ishibasi $M$, Shinzawa $H$, Kuboki $M$ et al. Prevalence of inhabitants with anti-hepatitis $\mathrm{C}$ virus antibody in an area following an acute hepatitis $\mathrm{C}$ epidemic: age and area-related features. Journal of Epidemiology 1996; 6:1-7.

24. Souto FJD, Espírito Santo GA, Philippi JC et al. Prevalência e fatores associados a marcadores do vírus da hepatite B em população rural do Brasil central. Revista Panamericana de Salud Pública 2001; 10:388-394.

25. Nacional Survey. Presented in: XX Brazilian Congress of Hepatology. Gramado - Brazil. 2009.

26. Rao MR, Naficy AB, Darwich MA et al. Further evidence for association of hepatitis $C$ infection with parenteral schistosomiasis treatment in Egypt. BMC Infectious Diseases 2002; 29:1-7.

27. Campiotto S, Pinho JR, Carrilho FJ et al. Geographic distribution of hepatitis $\mathrm{C}$ virus genotypes in Brazil. Brazilian Journal of Medical and Biological Research 2005; 38:41-49.

28. Focaccia R, Baraldo DCM, Ferraz MLG et al. Demographic and anthropometrical analysis and genotype distribution of chronic hepatitis $\mathrm{C}$ patients treated in public and private reference centers in Brazil. The Brazilian Journal of Infectious Diseases 2004; 8:348-355.

29. Espírito-Santo M., Carneiro MAS, Reis NRS et al. Genotyping hepatitis $\mathrm{C}$ virus from hemodialysis patients in Central Brazil by line probe assay sequence analysis. Brazilian Journal of Medical and Biological Research 2007; 40:545-550.

30. Desbois D, Vaghefi P, Savay J et al. Sensitivity of a rapid immuno-chromatographic test for hepatitis $\mathrm{C}$ antibodies detection. Journal of Clinical Virology 2008; 41:129-133. 